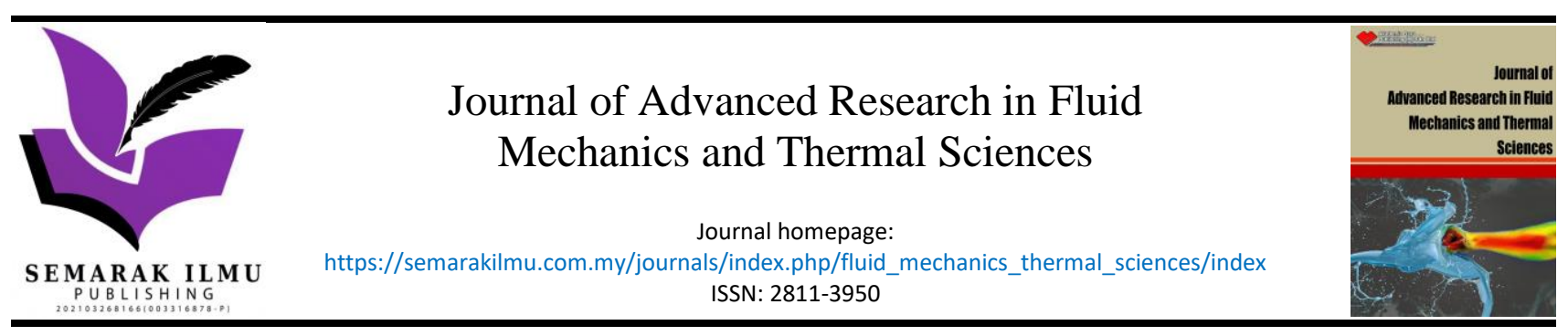

\title{
Designing a Solar Heat Storage System using Heat Pipe and Phase-Change Material (PCM)
}

\author{
Nasrullah Che Rahim ${ }^{1}$, Muhammad Fairuz Remeli ${ }^{1}{ }^{*}$, Baljit Singh ${ }^{1}$, Hazim Moria ${ }^{2}$ \\ 1 Energy Conservation for Automotive Research Group, School of Mechanical Engineering, College of Engineering, Universiti Teknologi MARA \\ (UiTM), 40450, Shah Alam, Selangor, Malaysia \\ 2 Department of Mechanical Engineering Technology, Yanbu Industrial College, Yanbu Al-Sinaiyah City 41912, Kingdom of Saudi Arabia College, \\ Saudi Arabia
}

ARTICLE INFO

\section{Article history:}

Received 14 September 2021

Received in revised form 2 December 2021

Accepted 23 December 2021

Available online 20 January 2022

\section{Keywords:}

Phase change material (PCM); Fresnel lens; Heat storage; Solar heat storage system

\section{ABSTRACT}

Phase change material (PCM) is used as a storage medium in a thermal heating system. The PCM's ability to store heat for a long time is suitable for combining with solar energy. PCM can absorb or release large amounts of latent heat at relatively constant temperatures. However, the PCM has poor thermal conductivity. The superconductive heat pipe is suitable to enhance the heat transfer in the PCM. The study aims to prove the concept of a unique thermal storage system that combines solar Fresnel lens, heat pipe, and phase change materials technologies. This study presented a detailed design and testing of the combined system under an actual outdoor environment. Four Fresnel lenses refracted the sunlight and focused on a heat collector. The lenses can be manually adjusted according to the sun's position. The heat is transferred to the PCM storage tank via a finned heat pipe. The testing results showed that the paraffin wax (PCM) has a melting temperature between $54-59{ }^{\circ} \mathrm{C}$. The highest temperature recorded in the paraffin wax tank was $121{ }^{\circ} \mathrm{C}$ which is suitable for many future applications. The system could store the heat up to $730 \mathrm{~kJ}$ by using $2 \mathrm{~kg}$ of paraffin. During the solidification of PCM (discharging), the system retained $120 \mathrm{~kJ}$ of heat for almost 7 hours with minimal heat loss. The system was proven to function well for storing the heat after the sunset, and it can be used for a passive power generation system, such as using thermoelectric cells.

\section{Introduction}

Thermal energy storage is the heat captured from hot solids and liquids and stores the energy for later use [1-2]. Solar energy is one of the sources of heat that can be stored. The primary components of the thermal energy storage system are the storage tank and heat storage medium [3-4]. This study used solar energy to store heat and the phase change material (PCM) as the storage medium. Solar energy is a renewable energy resource identified as a significant energy source, economically efficient, and reliable. There are numerous different forms of heat storage mediums that have been

\footnotetext{
* Corresponding author

E-mail address: fairuz1299@uitm.edu.my
}

https://doi.org/10.37934/arfmts.91.1.102114 
employed in industry, but PCM is the most productive since it uses latent heat.Using PCM is a valuable and advantageous method to get a high storage density with a higher efficiency [5-8].

For maintaining a certain amount of heat storage, only a small amount of PCM is required. PCM can store or release large amounts of energy at constant temperatures and has high thermal energy storage densities [9]. Hydrated salt and paraffin wax are the most widely used phase change materials [10-11]. Hydrated salt or liquid salt is found in some commercial-scale solar farms. At the same time, paraffin wax is more commonly used in residential storage or waste heat storage where operating temperatures are relatively low [12] [4]. Phase change material (PCM) uses latent heat to store thermal energy. The operation and design of latent heat thermal storage can be influenced by the PCM used. Because it may gain heat while remaining in its phase change state, the phase change material can also be used as a constant temperature heat source [13]. PCM can work permanently and experiences little degradation over time [1].

The phase change material (PCM) thermal storage is needed for a solar power system to ensure an endless solar energy supply for domestic or industrial applications such as water heating, airconditioning, waste heat utilization, and cooling. The high-energy storage density of phase change materials is essential for storing solar heat to reduce the space required for installation. PCM's physical and chemical characteristics are a significant factor in designing and operating the latent heat thermal storage [14]. The high-energy-density PCM should be selected for a high heat storage requirement. This will allow the designer to reduce the storage tank size. Such a design will cut costs for constructing a heat exchanger or provide a more significant storage capacity for the same volume.

Table 1 presented a critical assessment of the previous study trends integrating heat storage technology with various phase change materials and heat pipes.

Table 1

Summary of thermal energy storage using phase change materials (PCMs) and heat pipe

\begin{tabular}{|c|c|c|c|c|c|}
\hline $\begin{array}{l}\text { Author/ } \\
\text { Date }\end{array}$ & Topic/Focus & $\begin{array}{l}\text { Concept/ } \\
\text { Theoretical } \\
\text { Model }\end{array}$ & Method & Findings & $\begin{array}{l}\text { Limitations/ } \\
\text { Gaps }\end{array}$ \\
\hline [15] & $\begin{array}{l}\text { Energy storage using } \\
\text { novel organic phase } \\
\text { material/MXene } \\
\text { composite. }\end{array}$ & $\begin{array}{l}\text { Formulate novel } \\
\mathrm{PCM} / \mathrm{MXene} \\
\left(\mathrm{Ti}_{3} \mathrm{C}_{2}\right) \text { composite. }\end{array}$ & $\begin{array}{l}\text { Paraffin wax } \\
\text { (PCM) was } \\
\text { mixed with an } \\
\text { inorganic } \\
\text { nanoparticle } \\
\text { known MXene } \\
\text { with three } \\
\text { different } \\
\text { concentrations. }\end{array}$ & $\begin{array}{l}\text { Improving the } \\
\text { thermal } \\
\text { capacity, Cp by } \\
43 \% \text {, } \\
\text { absorbance } \\
\text { (UV-Vis) by 39\%, } \\
\text { and thermal } \\
\text { conductivity by } \\
16 \% \text { with } \\
\text { introducing } \\
3 \text { wt.\% mass } \\
\text { fraction of } \\
\text { MXene in the } \\
\text { composite. }\end{array}$ & $\begin{array}{l}\text { The melting } \\
\text { point of } \\
\text { PCM/MXene } \\
\text { could only be } \\
\text { increased by } 2^{\circ} \\
\text { C. It has a high } \\
\text { final } \\
\text { degradation } \\
\text { temperature of } \\
384^{\circ} \text { C. } \\
\text { However, the } \\
\text { study of the } \\
\text { size, thickness, } \\
\text { and number of } \\
\text { layers has not } \\
\text { been } \\
\text { conducted. }\end{array}$ \\
\hline [16] & $\begin{array}{l}\text { Heat management } \\
\text { using phase change } \\
\text { materials (PCM) and } \\
\text { heat pipe heat sink } \\
\text { Lithium-ion battery }\end{array}$ & $\begin{array}{l}\text { Study the } \\
\text { effectiveness of a } \\
\text { combination of } \\
\text { soy wax (PCM) } \\
\text { and heat pipe } \\
\text { heat sink for heat } \\
\text { management in }\end{array}$ & $\begin{array}{l}\text { Conducted four } \\
\text { different types } \\
\text { of battery } \\
\text { cooling } \\
\text { experiments } \\
\text { utilizing only } \\
\text { PCM, only a }\end{array}$ & $\begin{array}{l}\text { The combined } \\
\text { soy wax (PCM) } \\
\text { system and heat } \\
\text { pipes provided } \\
\text { the best } \\
\text { cooling, } \\
\text { lowering the }\end{array}$ & $\begin{array}{l}\text { Soy wax has a } \\
\text { slight } \\
\text { temperature } \\
\text { gap between } \\
\text { the melting } \\
\text { point }\left(44{ }^{\circ} \mathrm{C}\right) \text { and }\end{array}$ \\
\hline
\end{tabular}




an electric vehicle
Lithium-ion
battery.
Introduction of
graphene flakes
in paraffin wax to
increase the
thermal
conductivity of
the PCM.

[18]

[19]

[20]

\author{
Improved the \\ thermal and \\ electrical efficiency \\ of solar \\ concentrated \\ photovoltaic/therma \\ I (CPV/T) using \\ nanomaterials \\ composite of \\ graphene-silver (Gr- \\ $\mathrm{Ag}$ ) and paraffin \\ wax.
}

\section{Utilizing a novel nanocomposite of palmitic acid/ $/ \mathrm{Ti}_{3} \mathrm{C}_{2}$ MXene in the thermal energy storage system (TES).}

\section{Using fatty} acid/metal ion composite in thermal energy storage (TES) application.

[21] Integration of heat pipes and PCM in a solar still system

thermophysical

properties of a

hybrid graphene-

silver (Gr-Ag)

nanomaterial

mixed with

paraffin wax in a

solar thermal

system (CPV-T)

Improved

thermophysical

use of phase

change material

using palmitic

acid/Tii $\mathrm{C}_{2}$ MXene

composite.

The sodium - ion

has been

incorporated into

lauric acid to

improve its

thermophysical

properties.
Characterizing the Three different

A pulsating heat
pipe was
employed to
convey stored
heat in the PCM
to prevent saline
the thermal

$\begin{array}{ll}\begin{array}{l}\text { heat pipe heat } \\ \text { sink, no cooling, } \\ \text { and a mix of }\end{array} & \begin{array}{l}\text { battery } \\ \text { temperature by }\end{array} \\ \begin{array}{l}\text { PCM and heat } \\ \text { pipe heat sink. }\end{array} & \\ \begin{array}{l}\text { The parameters } \\ \text { that affect the }\end{array} & \text { The } \\ \text { themperature } \\ \text { conductivity of } & \text { was found to be } \\ \text { the nano-PCM- } & \text { influential } \\ \text { based graphene } & \text { parameter that } \\ \text { composite were } & \text { affects the } \\ \text { determined } & \text { nano-PCM- } \\ \text { using an } & \text { graphene-based } \\ \text { empirical model } & \text { thermal } \\ \text { created using a } & \text { conductivity. }\end{array}$

response

surface

approach.

compositions of

PCM/graphene-

silver have been

investigated.

Electrical and

thermal

performance

was predicted

using MATLAB

2017b

simulation.

solidification

$\left(38^{\circ} \mathrm{C}\right)$.

This model is adequately represented by the most critical independent variables, including the average lateral size of graphene flakes, mass fractions, and rising temperatures. Improvement of The thermal the specific heat and electrical capacity by $40 \%$ efficiency can and thermal only be conductivity by increased by $11 \%$ using $0.3 \quad$ less than $5 \%$ mass $\%$ of hybrid with the $\mathrm{PCM}$ /graphene introduction of silver.

hybrid PCM/graphene silver.

A two-step
process was
used to
synthesize the
palmitic
acid/ $\mathrm{Ti}_{3} \mathrm{C}_{2}$
$\mathrm{MXene}$
composite.
Sodium metal
with $0.2-1$
wt\% was doped
in lauric acid to
produce the
composite using
a simple
method.

The thermal The melting conductivity and temperature of conductivity increased by $14 \%$ and $4 \%$, respectively. the composition has not changed.

Enthalpy of The melting fusion was point of the enhanced by $11 \%$, and the temperature decomposition was improved by $30 \%$. composite decreased slightly as the weight percentage of sodium metal in the composite increased.

Latent heat of vaporization was recovered using a

Produced 6.3 The proposed $\mathrm{kg} / \mathrm{m}^{3}$ of fresh waste with an increase of $43 \%$ pulsating heat efficiency system's cost per liter (CPL) rose by $43 \%$ $\left(0.0093 \$ / \mathrm{L} / \mathrm{m}^{2}\right)$ compared to 


\begin{tabular}{|c|c|c|c|c|c|}
\hline & & $\begin{array}{l}\text { water } \\
\text { temperature } \\
\text { drops and } \\
\text { continuous } \\
\text { desalination after } \\
\text { sunset. }\end{array}$ & $\begin{array}{l}\text { a solar still } \\
\text { environment. }\end{array}$ & $\begin{array}{l}\text { typical passive } \\
\text { solar still } \\
\text { system. }\end{array}$ & $\begin{array}{l}\text { the standard } \\
\text { solar still } \\
\text { system. }\end{array}$ \\
\hline [22] & $\begin{array}{l}\text { Investigation of the } \\
\text { heat transfer } \\
\text { performance of the } \\
\text { combined heat pipe } \\
\text { and CuO-paraffin } \\
\text { nanocomposites. }\end{array}$ & $\begin{array}{l}\text { The heat transfer } \\
\text { characteristics of } \\
\text { heat pipe-PCM } \\
\text { were studied for } \\
\text { both cooling and } \\
\text { heating modes. }\end{array}$ & $\begin{array}{l}\text { The fin was } \\
\text { installed on the } \\
\text { condenser side } \\
\text { of the flat plate } \\
\text { heat pipe. The } \\
\text { PCM tank was } \\
\text { installed in the } \\
\text { adiabatic } \\
\text { section. }\end{array}$ & $\begin{array}{l}\text { The thermal } \\
\text { conductivity of } \\
\text { the PCMs rose } \\
\text { by } 24 \% \text { when } \\
1.2 \% \text { of CuO } \\
\text { nanoparticles } \\
\text { were doped into } \\
\text { the paraffin. }\end{array}$ & $\begin{array}{l}\text { PCMs latent } \\
\text { heat decreased } \\
\text { by } 1.5 \% \text {, and } \\
\text { the evaporator } \\
\text { temperature } \\
\text { reduced by } \\
17 \% \text {. }\end{array}$ \\
\hline [23] & $\begin{array}{l}\text { Investigation of a } \\
\text { wall cooling } \\
\text { technology using a } \\
\text { combination of a } \\
\text { microchannel heat } \\
\text { pipe, sky radiative } \\
\text { cooling, and PCM } \\
\text { (MHP-SC-PCM). }\end{array}$ & $\begin{array}{l}\text { Passive cooling of } \\
\text { sky radiation was } \\
\text { utilized via a } \\
\text { radioactive plate } \\
\text { for releasing heat } \\
\text { from the PCM } \\
\text { wall during the } \\
\text { nighttime. }\end{array}$ & $\begin{array}{l}\text { A preliminary } \\
\text { study was } \\
\text { conducted to } \\
\text { determine the } \\
\text { radiative plate } \\
\text { emissivity and } \\
\text { the paraffin } \\
\text { (RT28HC) } \\
\text { thermal } \\
\text { properties. A } \\
\text { numerical } \\
\text { model was } \\
\text { developed to } \\
\text { simulate the } \\
\text { MHP-SC-PCM } \\
\text { thermal } \\
\text { behavior. }\end{array}$ & $\begin{array}{l}\text { The system } \\
\text { could reduce } \\
\text { the cooling load } \\
\text { by } 4 \% \text {. }\end{array}$ & $\begin{array}{l}\text { The MHP-SC- } \\
\text { PCM wall was } \\
\text { able to a year- } \\
\text { round energy } \\
\text { saving of } 18 \% \\
\text { better than } \\
\text { typical wall } \\
\text { brick with the } \\
\text { same thickness. }\end{array}$ \\
\hline
\end{tabular}

Most recent studies focused on improving the thermal properties of PCM by adding additives, including carbon-based and metal-based materials. Carbon fillers have many advantages, such as having stable chemical and thermal properties, high thermal conductivity, and compact and low density. However, they are challenging to prepare and process. Metal-based fillers, meanwhile, can enhance the thermal conductivity of the PCM but have problems with high density and cannot be easily dispersed evenly, resulting in unstable heat transfer. They also are highly reactive with other substances [24].

Some studies added heat pipes, fins, and meshes to overcome the issue of low thermal conductivity and leaking problems. This study has chosen heat pipe because it has high thermal conductivity, is affordable, and long lifespan [25].

Therefore, this study features a unique solar thermal heat storage design consisting of Fresnel lenses, heat collector, heat pipes, phase change material, and a tank. The study aims to prove the workability of such a concept where its performance was tested and analyzed under real conditions. The study did not add any additives in the PCM to lower the cost of the system. Four pieces of Fresnel lens were placed under the sunlight to focus the heat onto the heat collector, as shown in Figure 1. A large number of Fresnel lenses are used because it can prevent system failure if one of them is damaged. In addition, it can be adjusted independently according to the position of the sun to focus light rays. Wider frames were adjustable, which they could rotate about 360 degrees to make sure the sun's heat is continuously focusing on the heat collector. With a $42 \mathrm{~mm} \times 37 \mathrm{~mm}$ dimension, the 
heat collector was connected to the heat pipe and fins, immersed in a thermal energy storage tank. The tank contained $2 \mathrm{~kg}$ of PCM to store enough heat for later use.

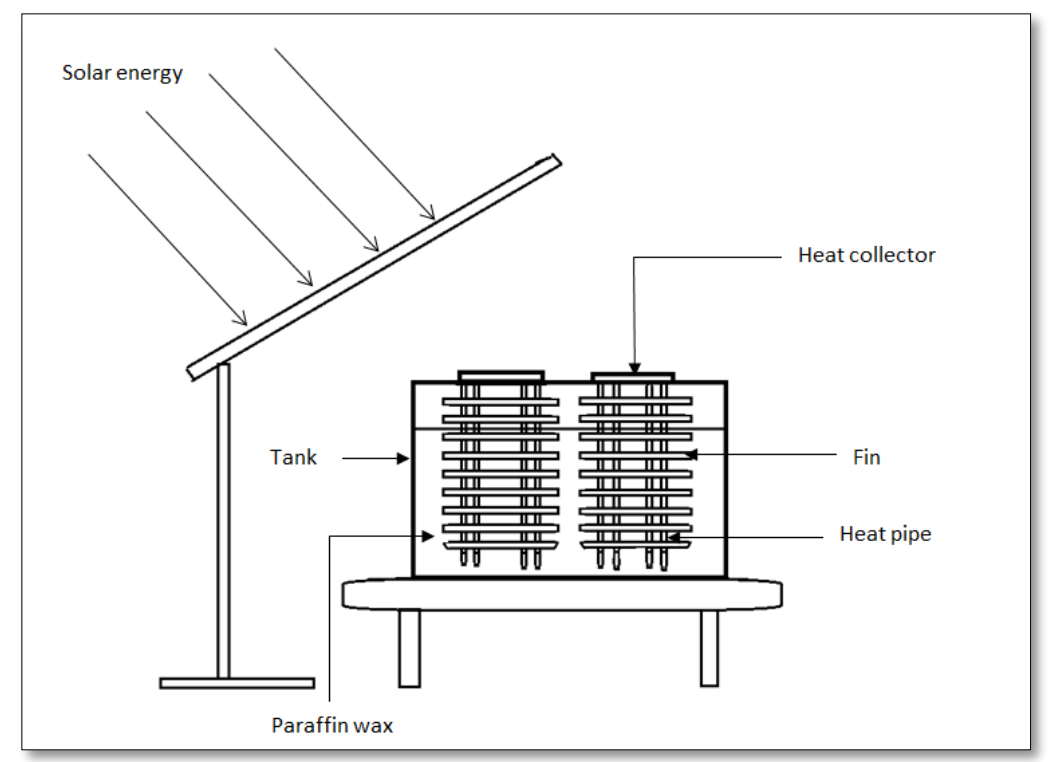

Fig. 1. An illustration of the experimental set-up

\section{Materials and Methods}

\subsection{Fresnel Lens}

Material selection for the model was decided based on reviewing the journals and related articles on solar Fresnel lenses. Most of the materials selected can easily absorb solar energy and convert it to heat energy at an optimum level. The Fresnel lens collector was mainly made from glass material with a glossy effect suitable for harnessing solar energy power to generate heat to the focal point of the heat pipe. The dimensions were taken according to the primary reference and scaled down so that the model can be placed on a level 21 Tower 1, Engineering Complex. However, the critical dimensions that need to be concerned are the Fresnel lens area, Fresnel lens collector area, the Fresnel lens stand's height, and the focal length. The dimension of the Fresnel lens is summarized in Table 2.

Table 2

Dimensions of the Fresnel lens

\begin{tabular}{ll}
\hline Descriptions & Dimensions, $\mathrm{mm}$ \\
\hline Fresnel lens area & $255 \times 180$ \\
Fresnel lens collector area & $42 \times 37$ \\
Length of the focal length & 250 \\
Height of the Fresnel lens stand & 1515 \\
\hline
\end{tabular}

\subsection{Thermal Energy Storage Tank Design and Heat Pipe}

The thermal energy storage tank's primary goal was to store heat and be used after the sun goes down for as long as needed. The storage tank systems require a practical design to release thermal energy at constant temperatures. An immaculate and effective heat transporting system must be built to enable waste heat flow into and out of the suggested PCM thermal storage concept. The characteristic information about the PCM thermal storage tank is given in Table 3. 
Table 3

Characteristics of Thermal Storage Tank

\begin{tabular}{ll}
\hline Parameter & Value \\
\hline Width: $\mathrm{mm}$ & 210 \\
Height: $\mathrm{mm}$ & 160 \\
Length: $\mathrm{mm}$ & 400 \\
Thickness: $\mathrm{mm}$ & 3 \\
Area: $\mathrm{m}^{2}$ & 0.084 \\
Volume: $\mathrm{m}^{3}$ & 0.01344 \\
\hline
\end{tabular}

Table 4 shows the characteristic of the heat pipe heat sink in the testing. Two sets of heat pipe heat sinks were placed in the tank.

Table 4

Characteristics of The Heat Pipe

\begin{tabular}{ll}
\hline Parameter & Properties/Value \\
\hline Material & Copper \\
Diameter: $\mathrm{mm}$ & 6 \\
Working fluid & water \\
Dimension $(\mathrm{L} \times \mathrm{W} \times \mathrm{H})$ & $80 \times 40 \times 117$ \\
\hline
\end{tabular}

\subsection{Phase Change Material}

The PCM used in thermal storage is paraffin wax, which is an organic material. It has a low melting point, with an enthalpy of fusion of $145-240 \mathrm{~kJ} / \mathrm{kg}$ [4]. It is non-corrosive, exhibits thermal cycling, and readily available. All these properties are essential requirements for developing a maintenancefree and reliable thermal storage system. Paraffin wax, known as PCM, will undergo a three-phase change in that solid-liquid and liquid phase to reach its melting point under constant heat dissipation by the heat pipe condenser section. The equation for calculating the heat storage capacity of the $\mathrm{PCM}$ is given as:

$Q_{s}=m_{p c m} C_{p p c m, \text { solid }}\left(T_{m}-T_{i}\right)+m_{p c m} L+m_{p c m} C_{p p c m, l i q u i d}\left(T_{f}-T_{m}\right)$

where $m_{p c m}$ is the mass of PCM $(\mathrm{kg}), T_{m}$ is the melting temperature, $T_{i}$ is the initial temperature, $T f$ is the PCM temperature, $C_{p}$ is the heat capacity $(\mathrm{kJ} / \mathrm{kg})$, and $\mathrm{L}$ is the latent heat $(\mathrm{kJ} / \mathrm{kg})$.

Table 5

Thermo-physical properties of proposed paraffin wax as PCM

\begin{tabular}{ll}
\hline Description & Value \\
\hline Melting temperature, ${ }^{\circ} \mathrm{C}$ & 53.7 \\
Mass, kg & 2 \\
Latent Heat Capacity, $\mathrm{kJ} / \mathrm{kg}[26]$ & 176 \\
Specific Heat Capacity, $\mathrm{Cp}$ PCM solid, kJ/kgK [27] & 2.95 \\
Specific Heat Capacity, $\mathrm{Cp}$ PCM liquid, kJ/kgK [27] & 2.51 \\
Initial temperature, ${ }^{\circ} \mathrm{C}$ & 32 \\
\hline
\end{tabular}

\subsection{Experimental Procedure}

The test began by setting four Fresnel lens pieces in its frames, as shown in Figure 2. The Fresnel lens was then placed under the sunlight to focus the ray onto the heat collector. The lens is adjustable 
and can be rotated at about 340 degrees. The distance between the Fresnel lens and the heat collector is about $0.25 \mathrm{~m}$. This distance is to ensure the solar radiation can precisely focus on the target (heat collector). The $42 \mathrm{~mm} \times 37 \mathrm{~mm}$ heat collector was connected to an evaporator side of a heat pipe. The other end of the heat pipe was finned, acts as a condenser, and is immersed in the thermal energy storage tank. The tank contains two kilograms of PCM. The radiation and ambient temperature were recorded by the solar emitter and wireless digital thermometer, respectively. Four temperature sensors at a specific location were connected to a data logger. The concentrators were adjusted to track the sun's position, and readings were obtained every 5 minutes. This is to make sure the bright spot is always at the center of the focal point (heat collector) to gain the highest heat energy from the sun.

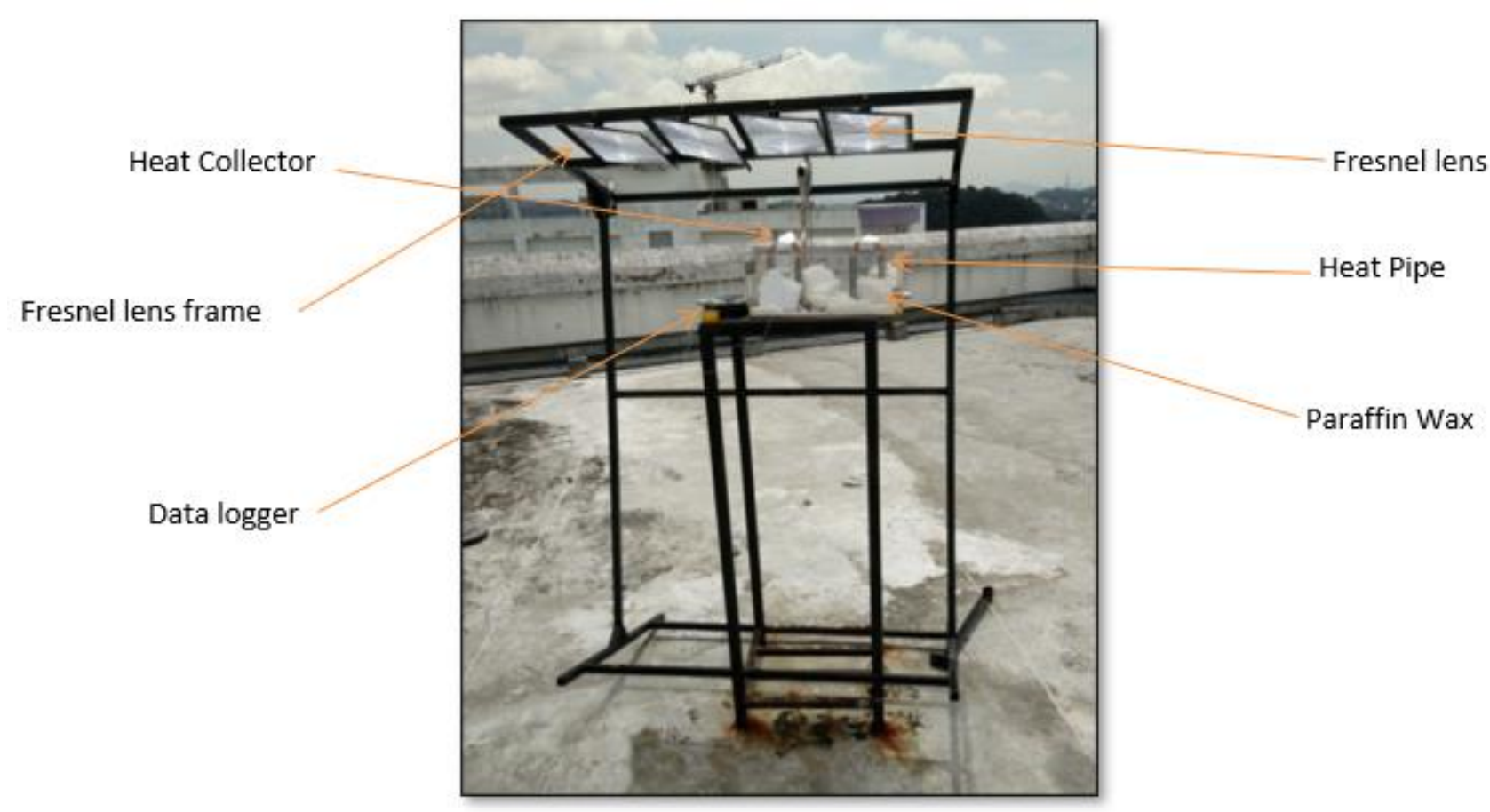

Fig. 2. Experimental set-up under the sunlight

\section{Result and Discussion}

Figure 3 shows the result of the preliminary test of the system. The collector temperature drastically increased from 3.10 p.m. until 3.40 p.m. Then, that brought it to a peak with a short duration, and the highest temperature was achieved at $116.1^{\circ} \mathrm{C}$ with $1110 \mathrm{~W} / \mathrm{m} 2$ solar radiation. The radiation reached the maximum plateau of the solar radiation between 3 p.m. until 5 p.m. The heat from the heat collector was transferred to the heat pipe, then lastly to the paraffin wax in the tank. The paraffin wax started to melt at $59.2^{\circ} \mathrm{C}$. Many clouds caused the temperature and solar radiation to drop slowly during the experiment due to convection heat loss. The experiments continued for another three days to collect reliable data. The data temperatures data were recorded using a data logger at the heat collector, heat pipe, paraffin wax (near to heat pipe), and paraffin wax (far from heat pipe). The data were collected from 3.28 p.m. to 4.19 p.m. due to good weather to run the experiment on day one. The highest temperature measured on the heat collector was $115{ }^{\circ} \mathrm{C}$ with $1149 \mathrm{~W} / \mathrm{m}^{2}$ of solar radiation, as shown in Figure 4. The heat from the heat collector was transferred to the heat pipe, and the highest temperature of the heat pipe was $101.6{ }^{\circ} \mathrm{C}$. Two temperature sensors were placed in the PCM tanks, the first was close to the heat pipe surface, and the second 
was at the bottom of the tank. Near the heat pipe, a combination of heat conduction and radiation caused a paraffin wax temperature to rise from $35^{\circ} \mathrm{C}$ to $56.7^{\circ} \mathrm{C}$ before reaching the melting point. The paraffin wax started to melt at 3.48 p.m., with a record temperature of $59.2^{\circ} \mathrm{C}$.

\section{Radiation and Temperature VS Time}

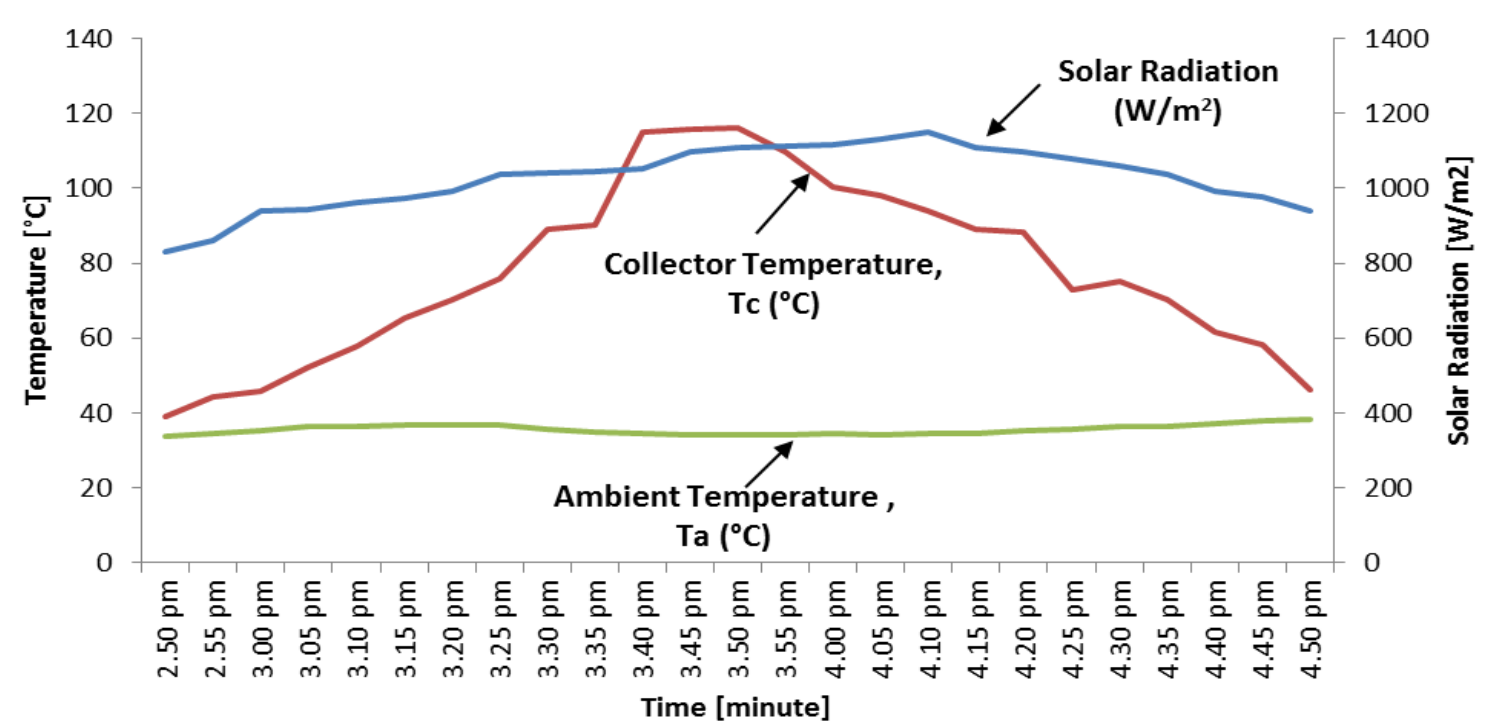

Fig. 3. The relationship between solar radiation and temperature

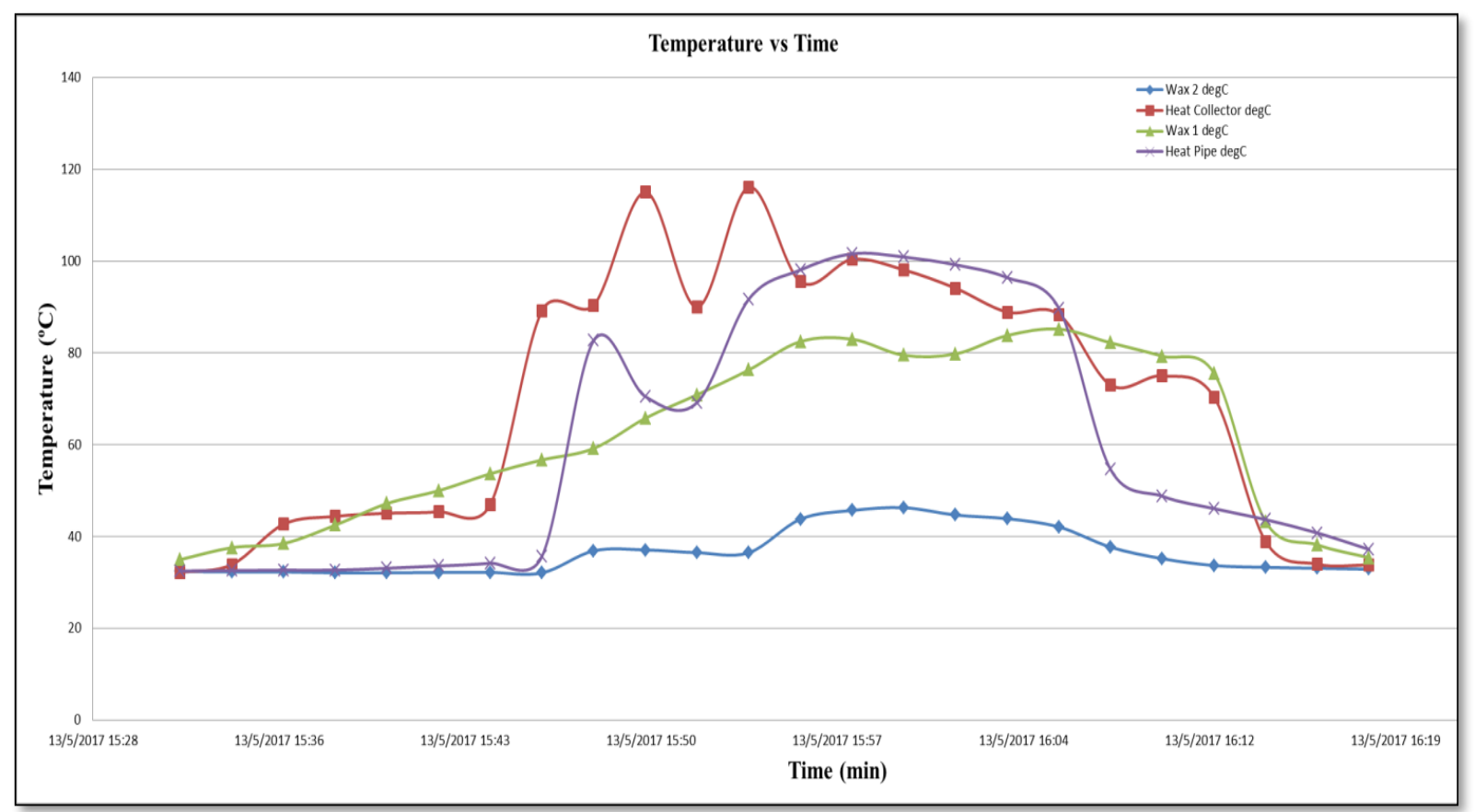

Fig. 4. Temperature Changes versus Time for Day One

Meanwhile, at the bottom of the paraffin wax tank, the temperature could only reach $46.3{ }^{\circ} \mathrm{C}$ because the heat could not be transferred efficiently. The sun became cloudy at 4.14 p.m., and the heat collector's temperature dropped from $116.1{ }^{\circ} \mathrm{C}$ to $46.2^{\circ} \mathrm{C}$. This caused the paraffin temperature to drop from $75.6{ }^{\circ} \mathrm{C}$ to $35.2{ }^{\circ} \mathrm{C}$. The two-kilogram paraffin wax was not wholly melted due to the gloomy weather. The paraffin wax can store the heat within the 1200 s (20 minutes) before returning 
to the experiment's average temperature. Figure 5 shows the molten paraffin wax (near to the heat pipe).

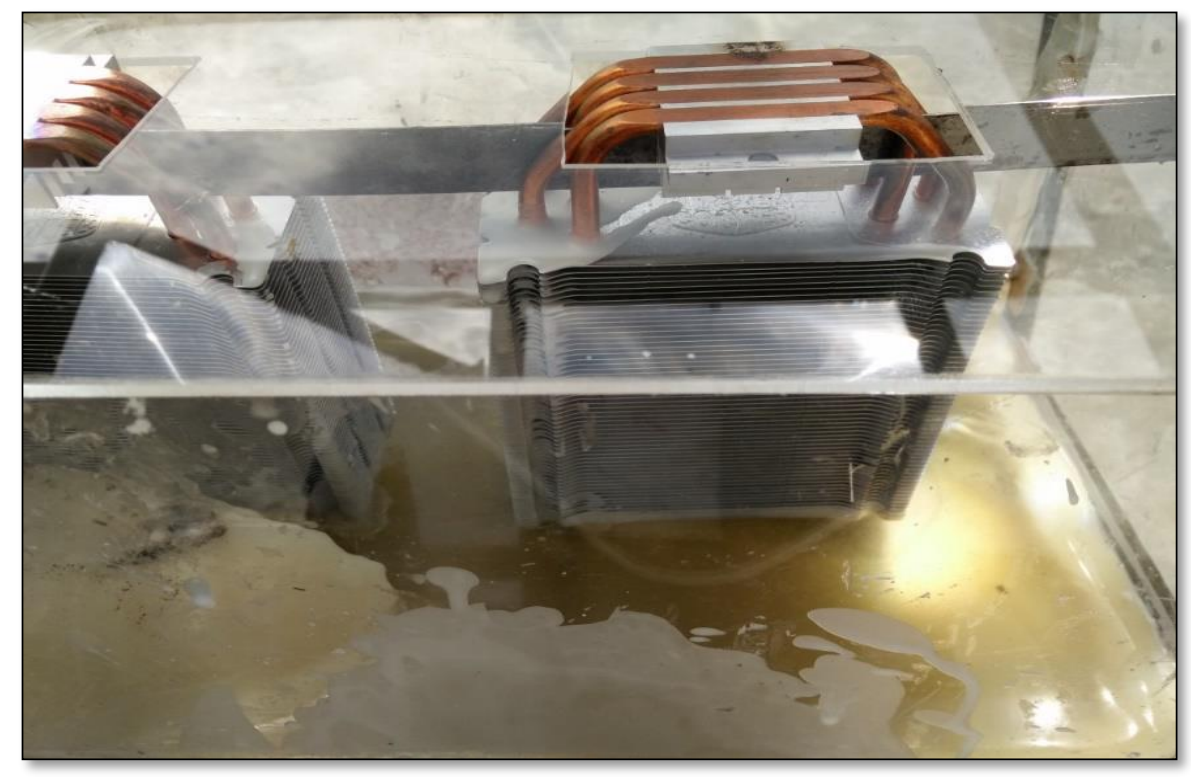

Fig. 5. Molten paraffin wax during testing

On day two, the data and the graph were collected and plotted using the data logger starting at 2.51 p.m. to 5.41 p.m., as shown in Figure 6. The paraffin wax (near to heat pipe) began to melt at 3.16 p.m., which reached the temperature of $53.4{ }^{\circ} \mathrm{C}$ and continued to melt until the paraffin wax changed from solid to liquid. The highest temperature of that phase change material was $104.5^{\circ} \mathrm{C}$. The fourth thermocouple at the bottom of the paraffin wax tank detected the temperature rise from $40.7^{\circ} \mathrm{C}$ to $78.3^{\circ} \mathrm{C}$ at 3.40 p.m. This is because the heat from the liquid wax started to diffuse toward the solid paraffin wax. Then, the day began cloudy at 3.51 p.m., and the temperature of the heat collector began to drop from $135.1^{\circ} \mathrm{C}$ to $114.3^{\circ} \mathrm{C}$. This condition affected the heat transfer rate to the heat pipe, which caused a decrease in temperature. The thermal storage tank was moved to a shady place at 4.00 p.m. to measure the paraffin wax's ability to store the heat absorbed earlier. The temperature of the paraffin wax (near the heat pipe) dropped from $77.7^{\circ} \mathrm{C}$ to $51.7^{\circ} \mathrm{C}$. It was found that the paraffin wax could store the heat for 6000 s (100 minutes) before it went back to the average temperature, which is $32.3^{\circ} \mathrm{C}$. 


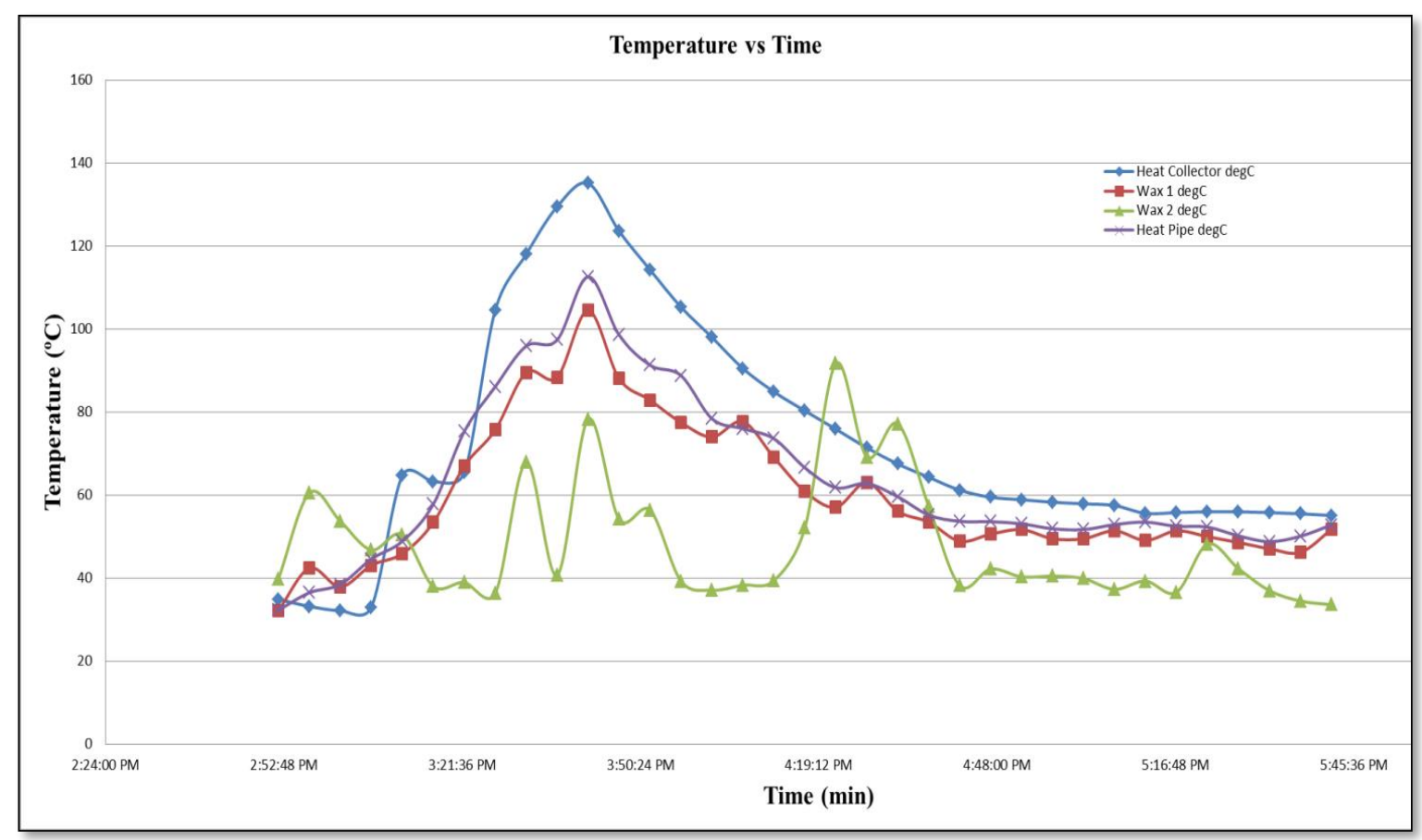

Fig. 6. Temperature Changes versus Time for Day Two

The experiment on day three is shown in Figure 7, starting at 12.43 p.m. to 10.43 p.m. Due to the excellent weather conditions, which was a sunny day and suitable for the experiment, took around ten hours to test the paraffin wax's ability to store the heat. The investigation showed that the heat collector's highest temperature was $121.3^{\circ} \mathrm{C}$, which had increased from $50.7^{\circ} \mathrm{C}$. The temperature of the heat pipe also rose from $33.7 \stackrel{\circ}{\circ}$ to $117.6 \stackrel{\circ}{\circ}$. The paraffin wax (near heat pipe) melted in the range of temperature of $53.7^{\circ} \mathrm{C}$ to $62.1^{\circ} \mathrm{C}$ at $2.03 \mathrm{p} . \mathrm{m}$. The heat from the heat pipe continued to flow to that paraffin wax, which caused the temperature to rise rapidly from $79.2{ }^{\circ} \mathrm{C}$ to $109{ }^{\circ} \mathrm{C}$, the highest temperature of the phase change material recorded. At 3.53 p.m., the fourth thermocouple at the bottom of the tank detected a temperature increase from $64.4{ }^{\circ} \mathrm{C}$ to $99.1{ }^{\circ} \mathrm{C}$. This is because the molten paraffin wax (near the heat pipe) is mixed with this paraffin wax. At 4.03 p.m., the availability of sun radiation started to drop. The heat collector's temperature decreased, followed by the heat pipe's temperature from $120.4{ }^{\circ} \mathrm{C}$ to $106.4^{\circ} \mathrm{C}$ and $117.6^{\circ} \mathrm{C}$ to $103.2^{\circ} \mathrm{C}$, respectively. At 4.33 p.m., the tank thermal storage was moved under a roof with no wind area. The heat collector was insulated with a rubber foam insulator. Figure 7 shows the paraffin wax's temperature (near to heat pipe) and (far from heat pipe) slowly decreased from $99.4{ }^{\circ} \mathrm{C}$ to $84.1{ }^{\circ} \mathrm{C}$ and $95.7{ }^{\circ} \mathrm{C}$ to $80{ }^{\circ} \mathrm{C}$, respectively. The results showed better heat retention as the heat slowly dissipated into the environment when the insulation was introduced in the third experiment. The phase change material can store the heat for longer than 6 hours ( 360 minutes) from 4.33 p.m. to 10.38 p.m. 


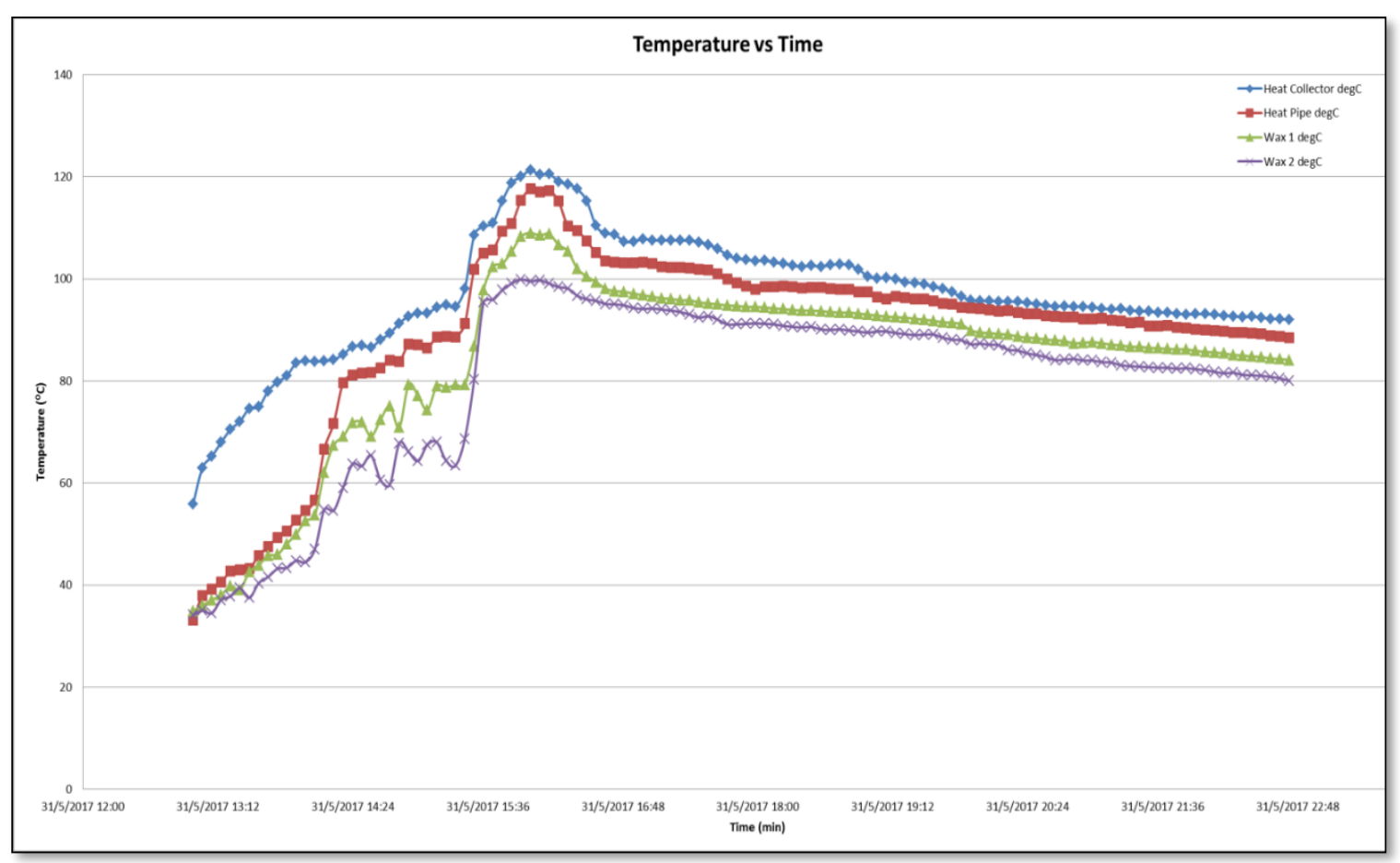

Fig. 7. Temperature Changes versus Time for Day Three

Figure 8 shows the storage capacity of paraffin wax from this experiment. Paraffin wax at room temperature heats up to a positive slope for the first 200 minutes. Heat storage reaches a peak capacity of $731 \mathrm{~kJ}$. The hot paraffin wax began to cool as the sun's rays started to disappear. Although this system seemed to lose energy due to a lack of solar radiation, there was still much heat left in the tank, with $621 \mathrm{~kJ}$ at the end of the testing period. This occurs after 6.75 hours ( 405 minutes). The slow process of removing heat or solidification back from paraffin shows that the system can store heat for a more extended period by installing an excellent insulation system.

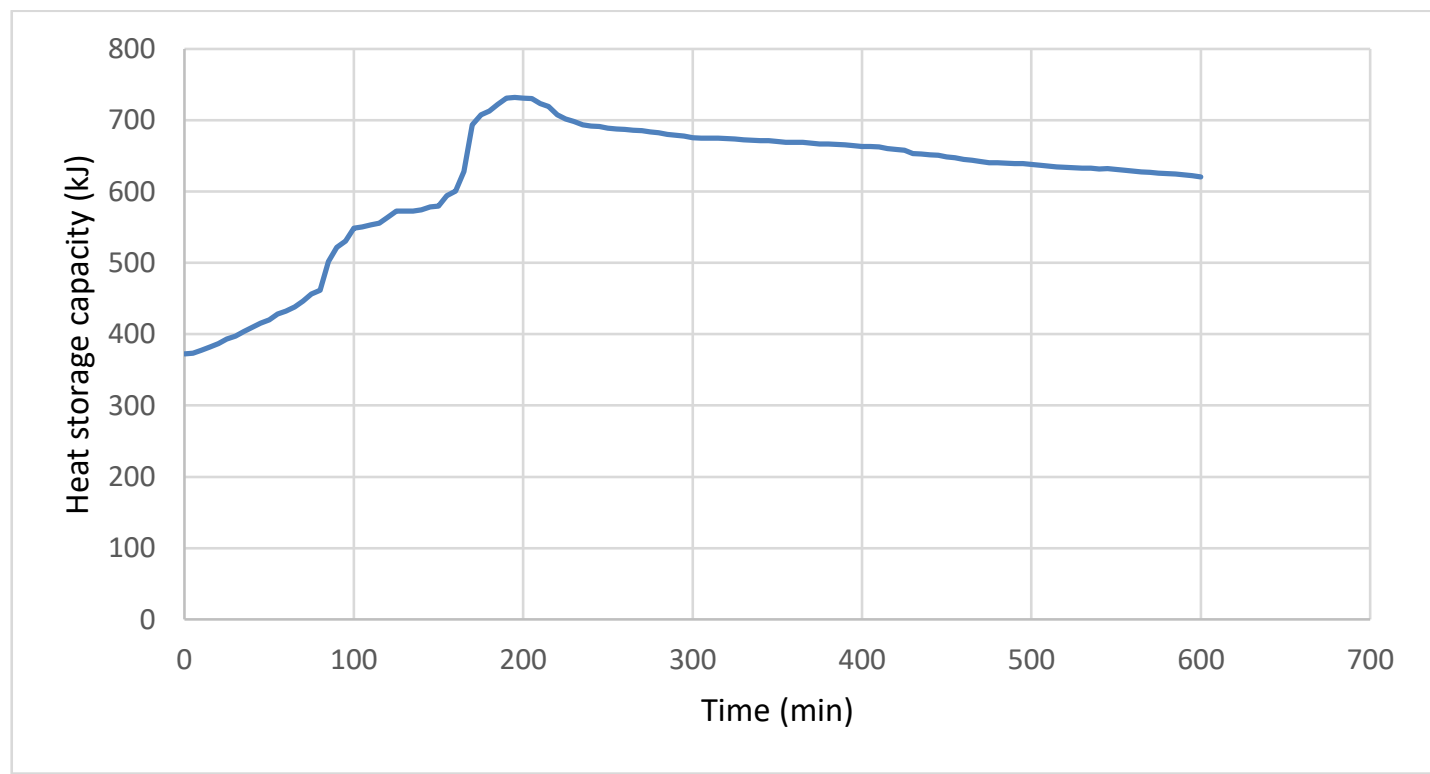

Fig. 8. Heat storage capacity versus time 


\section{Conclusions}

The experiments revealed that paraffin wax melts at temperatures ranging from 55 to $62{ }^{\circ} \mathrm{C}$. The maximum temperature of paraffin wax was $109^{\circ} \mathrm{C}$. Using the designed system, the $2 \mathrm{~kg}$ paraffin wax can retain heat energy from the sun for more than 400 minutes (6.6 hours). The highest recorded amount of energy stored was $730 \mathrm{~kJ}$. Even after 6 hours of cooling, there was still much heat stored in the paraffin tank, of which approximately $621 \mathrm{~kJ}$ remained. The paraffin liquid was expected to take a few more hours to solidify and return to ambient temperature with this amount of heat. The heat collector was connected to the heat pipe used. It was found that when the ambient temperature is lower than the tank temperature, the heat from the tank will move in the opposite direction due to the high efficiency of the heat pipe. This will accelerate heat loss from the tank to the surrounding area through the heat pipe and heat collector. The heat collector was insulated using rubber foam to overcome this problem. By insulating the heat collector, the paraffin wax could retain the heat for a more extended period. It was also found that if the mass of paraffin were increased, it would take a long time to dissolve paraffin wax. This is because paraffin wax is known to have low thermal conductivity. To further speed up the paraffin wax's heat transfer rate, increasing the number of heat pipes installed in the system is recommended, reducing the time to dilute paraffin.

\section{Acknowledgment}

This research was funded by $3 a$ grant from LESTARI (grant no: 600-RMC/MyRA 5/3/LESTARI (057/2020)) Universiti Teknologi MARA (UiTM).

\section{References}

[1] Nomura, Takahiro, Noriyuki Okinaka, and Tomohiro Akiyama. "Technology of latent heat storage for high temperature application: a review." ISIJ international 50, no. $9 \quad$ (2010): $1229-1239$. https://doi.org/10.2355/isijinternational.50.1229

[2] Gholamibozanjani, Gohar, and Mohammed Farid. "Application of an active PCM storage system into a building for heating/cooling load reduction." Energy 210 (2020): 118572. https://doi.org/10.1016/i.energy.2020.118572

[3] Ismaeel, Hatem Hasan, and Recep Yumrutaş. "Investigation of a solar assisted heat pump wheat drying system with underground thermal energy storage tank." Solar Energy 199 (2020): 538-551. https://doi.org/10.1016/j.solener.2020.02.022

[4] Regin, A. Felix, S. C. Solanki, and J. S. Saini. "Heat transfer characteristics of thermal energy storage system using PCM capsules: a review." Renewable and Sustainable Energy Reviews 12, no. 9 (2008): 2438-2458. https://doi.org/10.1016/i.rser.2007.06.009

[5] Drissi, Sarra, Tung-Chai Ling, and Kim Hung Mo. "Thermal performance of a solar energy storage concrete panel incorporating phase change material aggregates developed for thermal regulation in buildings." Renewable Energy 160 (2020): 817-829. https://doi.org/10.1016/i.renene.2020.06.076

[6] Tan, Lippong, Randeep Singh, and Aliakbar Akbarzadeh. "Thermal performance of two-phase closed thermosyphon in application of concentrated thermoelectric power generator using phase change material thermal storage." Frontiers in Heat Pipes (FHP) 2, no. 4 (2012). https://doi.org/10.5098/fhp.v2.4.3001

[7] Cabeza, Luisa F., Albert Castell, C. de Barreneche, A. De Gracia, and A. I. Fernández. "Materials used as PCM in thermal energy storage in buildings: A review." Renewable and Sustainable Energy Reviews 15, no. 3 (2011): 16751695. https://doi.org/10.1016/i.rser.2010.11.018

[8] Rashidi, S., H. Shamsabadi, J. A. Esfahani, and S. Harmand. "A review on potentials of coupling PCM storage modules to heat pipes and heat pumps." Journal of Thermal Analysis and Calorimetry 140, no. 4 (2020): 1655-1713. https://doi.org/10.1007/s10973-019-08930-1

[9] Pagkalos, Christos, George Dogkas, Maria K. Koukou, John Konstantaras, Kostas Lymperis, and Michail Gr Vrachopoulos. "Evaluation of water and paraffin PCM as storage media for use in thermal energy storage applications: A numerical approach." International Journal of Thermofluids 1 (2020): 100006. https://doi.org/10.1016/j.ijft.2019.100006

[10] He, Bo, and Fredrik Setterwall. "Technical grade paraffin waxes as phase change materials for cool thermal storage and cool storage systems capital cost estimation." Energy conversion and management 43, no. 13 (2002): 1709- 
1723. https://doi.org/10.1016/S0196-8904(01)00005-X

[11] Vakhshouri, Amir Reza. "Paraffin as phase change material." Paraffin Overview (2020): 1-23. https://doi.org/10.5772/intechopen.90487

[12] Rashmi, W., V. Mahesh, S. Anirban, P. Sharnil, and M. Khalid. "Hybrid Solar PVT Systems for Thermal Energy Storage: Role of Nanomaterials, Challenges, and Opportunities." In Energy Systems and Nanotechnology, pp. 131-160. Springer, Singapore, 2021.. https://doi.org/10.1007/978-981-16-1256-5 9

[13] Bédécarrats, J. P., F. Strub, B. Falcon, and J. P. Dumas. "Phase-change thermal energy storage using spherical capsules: performance of a test plant." International Journal of Refrigeration 19, no. 3 (1996): 187-196. https://doi.org/10.1016/0140-7007(95)00080-1

[14] Eftekhar, J., A. Haji-Sheikh, and D. Y. S. Lou. "Heat transfer enhancement in a paraffin wax thermal storage system." (1984): 299-306. https://doi.org/10.1115/1.3267599

[15] Aslfattahi, Navid, R. Saidur, A. Arifutzzaman, Rad Sadri, Nuno Bimbo, Mohd Faizul Mohd Sabri, Philip A. Maughan et al. "Experimental investigation of energy storage properties and thermal conductivity of a novel organic phase change material/MXene as A new class of nanocomposites." Journal of Energy Storage 27 (2020): 101115. https://doi.org/10.1016/i.est.2019.101115

[16] WafirulHadi, Mohamad, Titin Trisnadewi, and Nandy Putra. "Thermal Management System Based on Phase Change Material (PCM) and Heat Pipe in Lithium-ion Electric Vehicle Batteries." Journal of Advanced Research in Experimental Fluid Mechanics and Heat Transfer 3, no. 1 (2021): 26-35.

[17] Zendehboudi, Alireza, Navid Aslfattahi, Saidur Rahman, Mohd Faizul Mohd Sabri, Suhana Mohd Said, A. Arifutzzaman, and Nor Azwadi Che Sidik. "Optimization of thermal conductivity of NanoPCM-based graphene by response surface methodology." Journal of Advanced Research in Fluid Mechanics and Thermal Sciences 75, no. 3 (2020): 108-125. https://doi.org/10.37934/arfmts.75.3.108125

[18] Aslfattahi, Navid, R. Saidur, A. Arifutzzaman, A. S. Abdelrazik, L. Samylingam, Mohd Faizul Mohd Sabri, and Nor Azwadi Che Sidik. "Improved thermo-physical properties and energy efficiency of hybrid PCM/graphene-silver nanocomposite in a hybrid CPV/thermal solar system." Journal of Thermal Analysis and Calorimetry (2020): 1-18. https://doi.org/10.1007/s10973-020-10390-x

[19] Krishna, Yathin, R. Saidur, Navid Aslfattahi, M. Faizal, and K. C. Ng. "Enhancing the thermal properties of organic phase change material (palmitic acid) by doping MXene nanoflakes." In AIP Conference Proceedings, vol. 2233, no. 1, p. 020013. AIP Publishing LLC, 2020. https://doi.org/10.1063/5.0001366

[20] Krishna, Yathin, Navid Aslfattahi, R. Saidur, M. Faizal, and K. C. Ng. "Fatty acid/metal ion composite as thermal energy storage materials." SN Applied Sciences 2, no. 5 (2020): 1-10. https://doi.org/10.1007/s42452-020-2597-3

[21] Khalilmoghadam, Pooria, Abbas Rajabi-Ghahnavieh, and Mohammad Behshad Shafii. "A novel energy storage system for latent heat recovery in solar still using phase change material and pulsating heat pipe." Renewable Energy 163 (2021): 2115-2127. https://doi.org/10.1016/j.renene.2020.10.073

[22] Wang, Jin, Yanxin Li, Yao Wang, Li Yang, Xiangfei Kong, and Bengt Sundén. "Experimental investigation of heat transfer performance of a heat pipe combined with thermal energy storage materials of CuO-paraffin nanocomposites." Solar Energy 211 (2020): 928-937. https://doi.org/10.1016/i.solener.2020.10.033

[23] Yu, Cairui, Dongmei Shen, Wei He, Zhongting Hu, Sheng Zhang, and Wenfeng Chu. "Parametric analysis of the phase change material wall combining with micro-channel heat pipe and sky radiative cooling technology." Renewable Energy 178 (2021): 1057-1069. https://doi.org/10.1016/i.renene.2021.07.001

[24] Lin, Yaxue, Yuting Jia, Guruprasad Alva, and Guiyin Fang. "Review on thermal conductivity enhancement, thermal properties and applications of phase change materials in thermal energy storage." Renewable and sustainable energy reviews 82 (2018): 2730-2742. https://doi.org/10.1016/i.rser.2017.10.002

[25] Behi, Hamidreza, Danial Karimi, Foad Heidari Gandoman, Mohsen Akbarzadeh, Sahar Khaleghi, Theodoros Kalogiannis, Md Sazzad Hosen, Joris Jaguemont, Joeri Van Mierlo, and Maitane Berecibar. "PCM assisted heat pipe cooling system for the thermal management of an LTO cell for high-current profiles." Case Studies in Thermal Engineering 25 (2021): 100920. https://doi.org/10.1016/j.csite.2021.100920

[26] Nithyanandam, K., and R. Pitchumani. "Computational modeling of dynamic response of a latent thermal energy storage system with embedded heat pipes." Journal of solar energy engineering 136, no. 1 (2014). https://doi.org/10.1115/1.4024745

[27] Himran, Syukri, Aryadi Suwono, and G. Ali Mansoori. "Characterization of alkanes and paraffin waxes for application as phase change energy storage medium." Energy sources 16, no. 1 (1994): 117-128. https://doi.org/10.1080/00908319408909065 